\title{
Biatrial Volume Reduction Surgery in Management of Atrial Fibrillation
}

\author{
Atriyal Fibrilasyon Tedavisinde Biatriyal Hacim Küçültme Cerrahisi
}

\author{
Sefer Usta' ${ }^{1}$, Hamit Serdar Bașbuğ², Gökhan Özerdem³ \\ ${ }^{I}$ Department of Cardiovascular Surgery, Ahi Evren Thoracic and Cardiovascular Surgery Training and Research Hospital, Trabzon, \\ Turkey; ${ }^{2}$ Department of Cardiovascular Surgery, Kafkas University Faculty of Medicine, Kars, Turkey; ${ }^{3}$ Department of Cardiovascular \\ Surgery, Private Sevgi Hospital, Kayseri, Turkey
}

\begin{abstract}
AIM: In this study, we aimed to demonstrate the efficiency of biatrial volume reduction surgery and investigate the outcomes of the atrial mass decrease in the treatment of atrial fibrillation (AF) among the patients with a significant increase in atrial diameter. It is performed together with mitral and tricuspid valve surgery together with the ablation procedure in patients with AF.

METHODS: Between March 2012 and January 2015, twenty-three cases with mitral valvular pathology with coexisting $A F$ and biatrial dilatation treated with biatrial volume reduction operation along with the mitral and tricuspid valve surgery were included the study. Preoperative and postoperative data were retrospectively evaluated.

RESULTS: Out of twenty-three patients, twelve patients were applied tricuspid ring annuloplasty and eleven patients were treated with DeVega annuloplasty. Mitral valve replacement (MVR) process was performed in all 23 patients. Biatrial volume reduction was done in all patients. While the preoperative left and right atrial diameters were $70 \pm 20 \mathrm{~mm}$ and $65 \pm 21 \mathrm{~mm}$, the average of postoperative left atrial and right atrial diameters were measured $50 \pm 14$ $\mathrm{mm}$ and $45 \pm 8 \mathrm{~mm}$ respectively. Sinus rhythm was achieved in all patients at the end of the operations.

CONCLUSION: One of the important factors affecting the success of the treatment of AF is the atrium diameter. The sizes of both atria in the electrophysiological studies are seen as the most important factor for the development of permanent AF. Atrial volume reduction operations are thought to be necessary for the achievement of sinus rhythm.
\end{abstract}

Key words: atrial fibrillation; biatrial volume reduction; ablation; surgery

\section{ÖZET}

AMAÇ: Bu çalıșmada, atriyum çapları ileri derecede artmıș atriyal fibrilasyon (AF) hastalarında, biatriyal hacim küçültme ameliyatlarının etkinliğinin gösterilmesi ve atriyum kütlesindeki azalmanın AF

Yard. Doç. Dr. Hamit Serdar Başbuğ, Kafkas Üniversitesi Tip Fakültesi Kalp ve Damar Cerrahisi Paşaçayırı Kars - Türkiye, Tel. 04742251149

Email.s_basbug@hotmail.com

Geliş Taribi: 01.03.2015 • Kabul Taribi: 21.04.2015 tedavisi üzerindeki etkilerinin araștırılması amaçlanmıștır. Atriyum küçültmesi, AF hastalarında mitral ve triküspid kapak cerrahisine ek olarak ablasyon ișlemi ile birlikte uygulanmıștır.

YÖNTEM: Mart 2012 ile Ocak 2015 tarihleri arasında mitral ve triküspid kapak patolojisi ile birlikte biatriyal dilatasyonu olan ve tedavisinde mitral ve triküspid kapak cerrahisi ile birlikte biatriyal hacim küçültme operasyonu uygulanan yirmiüç AF hastası çalıșmaya dahil edildi. Preoperative ve postoperative veriler retrospektif olarak incelendi.

BULGULAR: Yirmi üç hastanın, onikisinde triküspid ring annuloplasti, onbir hastada ise DeVega annuloplasti uygulandı. Hastaların tümünde mitral kapak replasmanı (MVR) yapıldı. Biatriyal hacim küçültme tüm hastalara uygulandı. Ortalama preoperatif atrium çapları sol ve sağ sırasıyla $70 \pm 20 \mathrm{~mm}$ ve $65 \pm 21 \mathrm{~mm}$ iken, postoperatif sol ve sağ atrial çaplar, sırasıyla $50 \pm 14 \mathrm{~mm}$ ve $45 \pm 8 \mathrm{~mm}$ olarak ölçüldü. Postoperatif atriyal çaplarda belirgin azalma sağlandı. Tüm hastalar operasyon sonunda sinüs ritmine döndü.

SONUÇ: AF tedavisinin bașarısını etkileyen önemli faktörlerden biri de atrium çapıdır. Elektrofizyolojik çalıșmalarda, atriyum boyutlarının kalıcı AF gelișmesinde en önemli faktörlerden biri olduğu gösterilmiștir. Sinüs ritminin yakalanmasında atriyum hacim küçültme ameliyatlarının gerekli olduğunu düșünmekteyiz.

Anahtar kelimeler: atriyal fibrilasyon; biatriyal hacim küçültme; ablasyon; cerrahi

\section{Introduction}

Atrial fibrillation (AF) is a cardiac rhythm anomaly affecting $0.4-1 \%$ of all population. It is demonstrated in $40-60 \%$ of the patients with mitral valvular disease and $5-10 \%$ of the patients scheduled for coronary artery bypass grafting (CABG) operation ${ }^{1}$. Additionally, $2 \%$ of all patients with AF demonstrates no cardiopulmonary pathology ${ }^{2}$. Prevalence is higher in older age, male gender, and in the presence of impaired left ventricular function. Failure rates of medical treatment are $50 \%$ at the end of the first year and $84 \%$ at the end of the second year ${ }^{3}$. The success rates of the radiofrequency 
ablation (RFA) during mitral valve surgery are still unsatisfactory regarding the treatment of AF. Atrium diameter directly affects the success of the treatment ${ }^{4}$.

The arrhythmia surgery for the treatment of AF has a significant role in valvular pathologies with the developments in heart surgery. Various surgical methods were performed for the AF treatment so far. In 1914, Garrey reported that the mass size of the atrium is important in the formation and the continuation of AF. Surgical remodelling of the atria was considered as an important factor for the treatment of AF via preventing the macro-waves due to the increased atrial mass ${ }^{5}$. As soon as the macro-waves were blocked, a normal sinus activation could be achieved with the Maze procedure or RFA. In most studies, a direct relationship between the surgical correction of AF and the reduction of atrial size was demonstrated. Regarding the conversion to the sinus rhythm, left atrium (LA) diameters below $45 \mathrm{~mm}$ reveals a nearly $100 \%$ success with the Maze procedure ${ }^{6}$. Left atrial isolation procedure was initially applied in 1980 by Cox and his colleagues. Atrioventricular (AV) node catheter ablation was performed in 1982 by Scheinman, and the corridor method was used by Guiraudon in 1985. Then the atrial transaction procedure has been developed. None of these methods had a provision of sinus rhythm, AV synchronization or eliminating the risk of thromboembolism. However, Maze (cut and sew) operation that was introduced in 1980 by James Cox and his colleagues achieved significant progression in this area. High success was obtained with Cox-Maze III method in patients with AF, which was refractory to medical treatment ${ }^{7}$.

Regarding the atrial remodeling, weight, area, maximum and minimum dimensions of the atria are considered equally for the permanent treatment of AF. The size of both atria in the electrophysiological studies are seen as the most important factor for the formation of permanent $\mathrm{AF}^{8}$. For this reason, the success of RFA treatment for AF during mitral valve surgery mostly depends on the atrial volume reduction surgery. Additionally, growth of atrium in mitral valve disease accompanies the respiratory system dysfunction due to mechanical compression. Especially, in case of a giant left atrium, complications related to the bronchial compression of the lungs have reported ${ }^{9}$.

In this article, we report a series of atrial volume reduction surgery in 23 cases presented with a simultaneous $\mathrm{AF}$ and mitral and tricuspid valve disease requiring mitral and tricuspid valve surgery.

\section{Patient and Methods}

The study was performed multicentrically by the cardiovascular surgery departments of Ahi Evren Thoracic and Cardiovascular Surgery, Trabzon, Turkey and Private Sevgi Hospital, Kayseri, Turkey. Twentythree cases with mitral valvular pathology with coexisting $\mathrm{AF}$ and biatrial dilatation were included in the study between March 2012 and January 2015. Biatrial volume reduction operation was performed in all cases along with the mitral and tricuspid valve surgery. Right and left atrial diameters were measured preoperatively and postoperatively by using Transthoracic echocardiography (TTE) and trans-esophageal echocardiography (TEE). Data were collected retrospectively. Patient demographics and cardiac parameters were demonstrated in Table 1. Accompanying comorbidity and cross-clemp time were given in Table 2 .

Table 1. Patient demographics and cardiac parameters

\begin{tabular}{|c|c|}
\hline The average age & $47 \pm 12$ \\
\hline Gender (F/M) & $14 / 9$ \\
\hline $\begin{array}{l}\text { Mitral Stenosis } \\
\text { (Moderate \& Severe) }\end{array}$ & 10 \\
\hline $\begin{array}{l}\text { Mitral Insufficiency } \\
\text { (Moderate \& Severe) }\end{array}$ & 8 \\
\hline Mitral Stenosis + Mitral Insufficiency & 5 \\
\hline Additional tricuspid Insufficiency & 23 \\
\hline $\begin{array}{l}\text { Preoperative. } \\
\text { Left and right atrial diameter }\end{array}$ & $70 \pm 20 \mathrm{~mm} / 65 \pm 21 \mathrm{~mm}$ \\
\hline $\begin{array}{l}\text { Postoperative. } \\
\text { Left and right atrial diameter }\end{array}$ & $50 \pm 14 \mathrm{~mm} / 45 \pm 8 \mathrm{~mm}$ \\
\hline $\begin{array}{l}\text { Percentage of patients } \\
\text { with atrial fibrillation }\end{array}$ & $\% 100$ \\
\hline NYHA Classification & Class $3(\% 91)$; Class $4(\% 9)$ \\
\hline The average LVEF & $\% 50 \pm 5$ \\
\hline Average arterial blood pressure & $80 \pm 6 \mathrm{mmHg}$ \\
\hline Average pulmonary artery pressure & $41 \pm 9 \mathrm{mmHg}$ \\
\hline Pulmonary vascular resistance & $3.2 \pm 1.4 \mathrm{mmHg}$ \\
\hline Cardiac index $\left(\mathrm{L} / \mathrm{min} / \mathrm{m}^{2}\right)$ & $2.6 \pm 0.7$ \\
\hline Stroke volume index $\left(\mathrm{ml} / \mathrm{m}^{2}\right)$ & $36 \pm 6$ \\
\hline
\end{tabular}


Table 2. Comorbidity and cross-clemp time

\begin{tabular}{ll}
\hline Diabetes & 3 \\
Hypertension & 8 \\
COPD & 2 \\
Preoperative antiarrhythmic & 20 \\
Patients over 60 years & 0 \\
Cross-clamp time (min) & $73.43 \pm 14.21$ \\
\hline COPD: Chronic Obstructive Pulmonary Disease &
\end{tabular}

\section{Surgical Technique}

Mediastinum was reached under general anesthesia with median sternotomy. Extracorporeal circulation was established with a standard aortic and venous bicaval canulation. Cardiac arrest was achieved with moderate hypothermia $\left(28-32 \mathrm{C}^{\circ}\right)$. Antegrade cardioplegic solution with a dose of $10 \mathrm{ml} / \mathrm{kg}$ was given after the aortic x-clemp was placed. Intermittant cardioplegia was administered via retrograde cannula through the coronary sinus in every twenty minutes. Standard mitral valve replacement (MVR) with mechanical prosthetic heart valve was performed in all patients. DeVega or ring annuloplasty was performed in all patients as they all had additional tricuspid insufficiency. RFA was applied to all patients. Transseptal biatrial volume reduction was achieved by the superior transeptal approach to all patients (Fig. 1). Patients were followed for one-year postoperatively in terms of the AF recurrence.

\section{Results}

Nine of the cases were females, and 14 were men. The average age was $47 \pm 12$ years. Average preoperative left and right atrial diameters were measured at $70 \pm 20 \mathrm{~mm}$ and $65 \pm 21 \mathrm{~mm}$ respectively (Fig 2). MVR operation was performed in all 23 patients. Tricuspid ring annuloplasty was performed in 12 patients. Eleven patients were treated with DeVega annuloplasty. Tricuspid annuloplasties were performed following MVR procedures. Biatrial volume reduction was achieved in all patients. No revision operation was needed postoperatively due to bleeding or any other reasons. None of the patients required pacing. The average of postoperative left atrial and right atrial diameters were measured $50 \pm 14 \mathrm{~mm}$ and $45 \pm 8 \mathrm{~mm}$ respectively. Amiodarone was started to all patients postoperatively as an antiarrhythmic. After being followed two days in intensive care and 5-6 days in service they were discharged. Patients were followed one year after their operation. No mortality was occurred in one year. After one-year follow-up, 14 patients $(60.86 \%)$ were in sinus rhythm, 6 patients $(26.08 \%)$ were in paroxysmal AF and 3 patients $(13.06 \%)$ were in permanent AF.
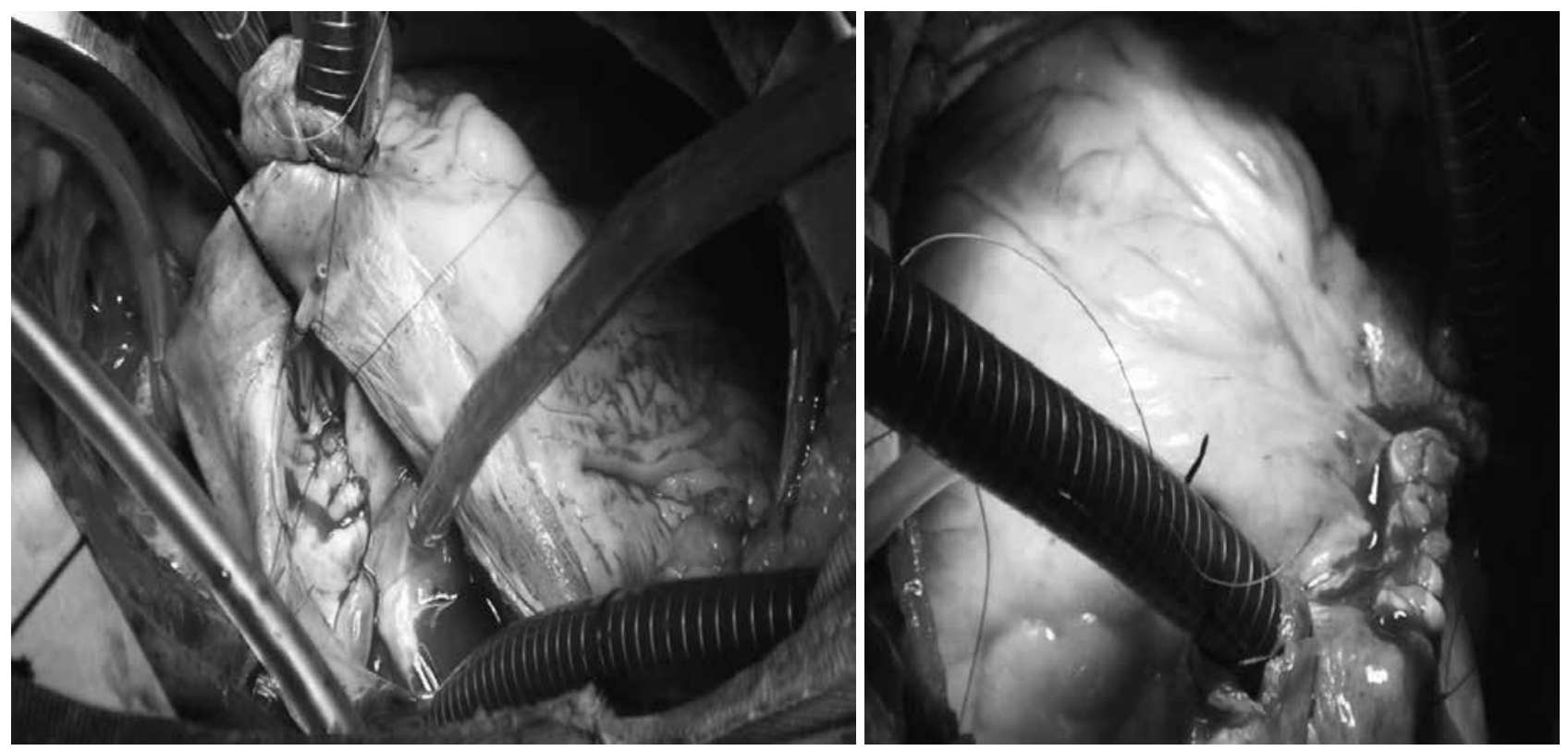

Figure 1. a, b. Intraoperative pictures of left (a) and right (b) atrial remodelling. 


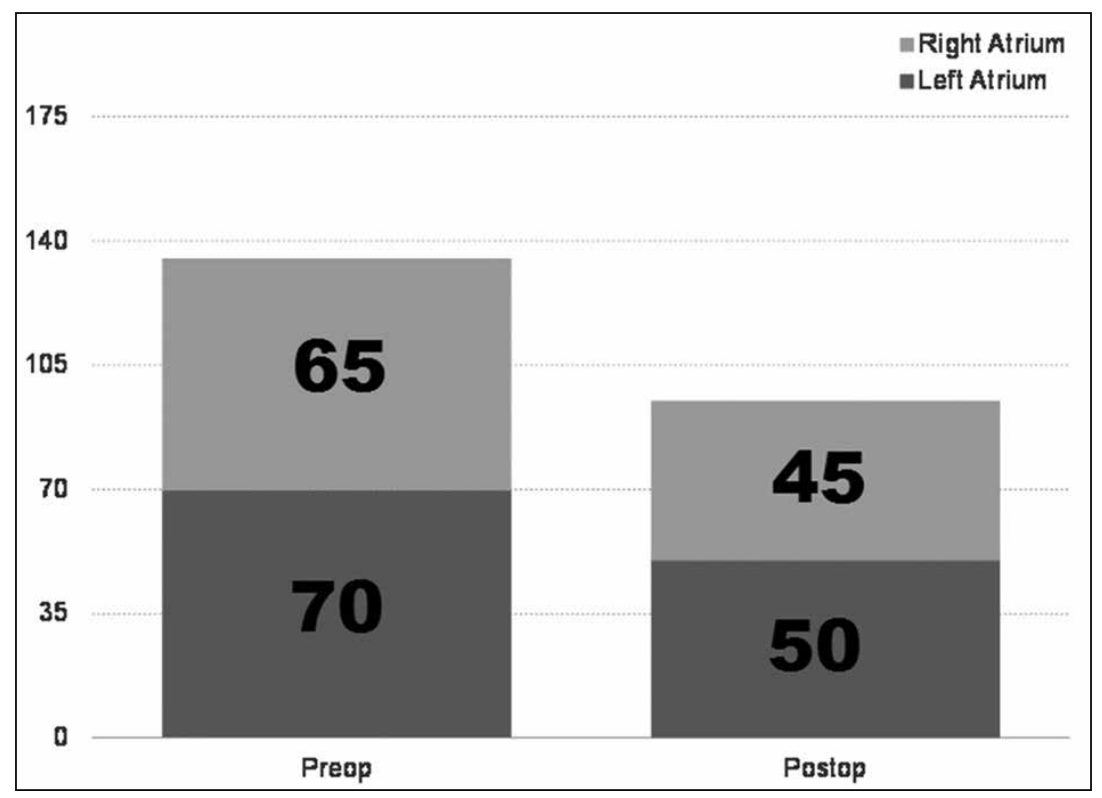

Figure 2. Preoperative and postoperative atrium diameters.

\section{Discussion}

Regarding the mitral valve surgery, AF becomes determinant as a permanent risk factor for the mortality ${ }^{1}$. The potential ventricular proarrhythmic effects of antiarrhythmic drugs were also demonstrated in various studies ${ }^{10}$. For this reason, consideration of the arrhythmia surgery along with mitral valve surgery should be evaluated as a treatment of choice in AF patients ${ }^{3}$. In our study, we performed AF operation with valvular correction as well as atrial resizing. In most studies, electrical activations in the right atrium proved to be more complicated than the left atrium and associated with the presence of permanent AF. It was also revealed that the left atrium isolation would not only be sufficient, but insulation in the right atrium was also necessary ${ }^{2}$. For this reason, re-entry activations in the right atrium necessitate biatrial incision and the pulmonary isolation as a complete treatment. Surgical blocking of the activation of both atria achieved an $89 \%$ success in providing the sinus rhyth $\mathrm{m}^{4}$. In addition, the recurrence of AF is greater in a large atrium ${ }^{5}$. Prevention of postoperative thromboembolic complications and restoration of the impaired hemodynamic status are considered as the supplementary objectives of the atrium reduction operation. Left ventricular pressure is decreased by the left atrial de-sizing as the posterobazal wall of the heart would no longer be compressed by the atrial mass. It is known that large atrium tissue and its extent causes paroxysmal arryythmia in patients with a chronic $\mathrm{AF}^{3}$. In order to prevent these complications, resection and plication techniques during mitral valve surgery have been reported for the left atrial volume reduction ${ }^{5}$.

In this study, the valvular pathologies were surgically corrected as well as the atrial sizes were reduced. The mean preoperative left and right atrium diameters were $70 \pm 20 \mathrm{~mm}$ and $65 \pm 21$. However, the postoperative diameters were reduced to $50 \pm 14 \mathrm{~mm}$ and $45 \pm 8 \mathrm{~mm}$ respectively (Fig. 2 ). This data indicates $20 \pm 6 \mathrm{~mm}$ volume reduction in left atrium ( $40 \%$ of reduction) and $25 \pm 12 \mathrm{~mm}$ in right atrium (35.7\% of reduction). These measurements indicates the efficiency of our surgical method in reduction of the atrial diameters. The atrial diameters are not only enough in maintaining the sinus rhythm. Regarding the surgical treatment of AF, left atrial ablation including mitral annulus is also essential for the maintenance of the sinus rhythm ${ }^{7}$. However, the size of the mass of atrial tissue is also known to be important for macro-waves. Biatrial reduction is an ideal method of treatment to restore the normal atrial geometry. Isolation of the left atrium appendix alone cuts leading AF foci and restricts re-entry fields ${ }^{11}$.

Out of twenty-three of patients, 14 of them (60.86\%) maintained their sinus rhythm after one year following the surgery. Nine patients were lost the sinus rhythm. Out of these nine patients, six patients were in paroxysmal atrial tachycardia and three patients were turned 

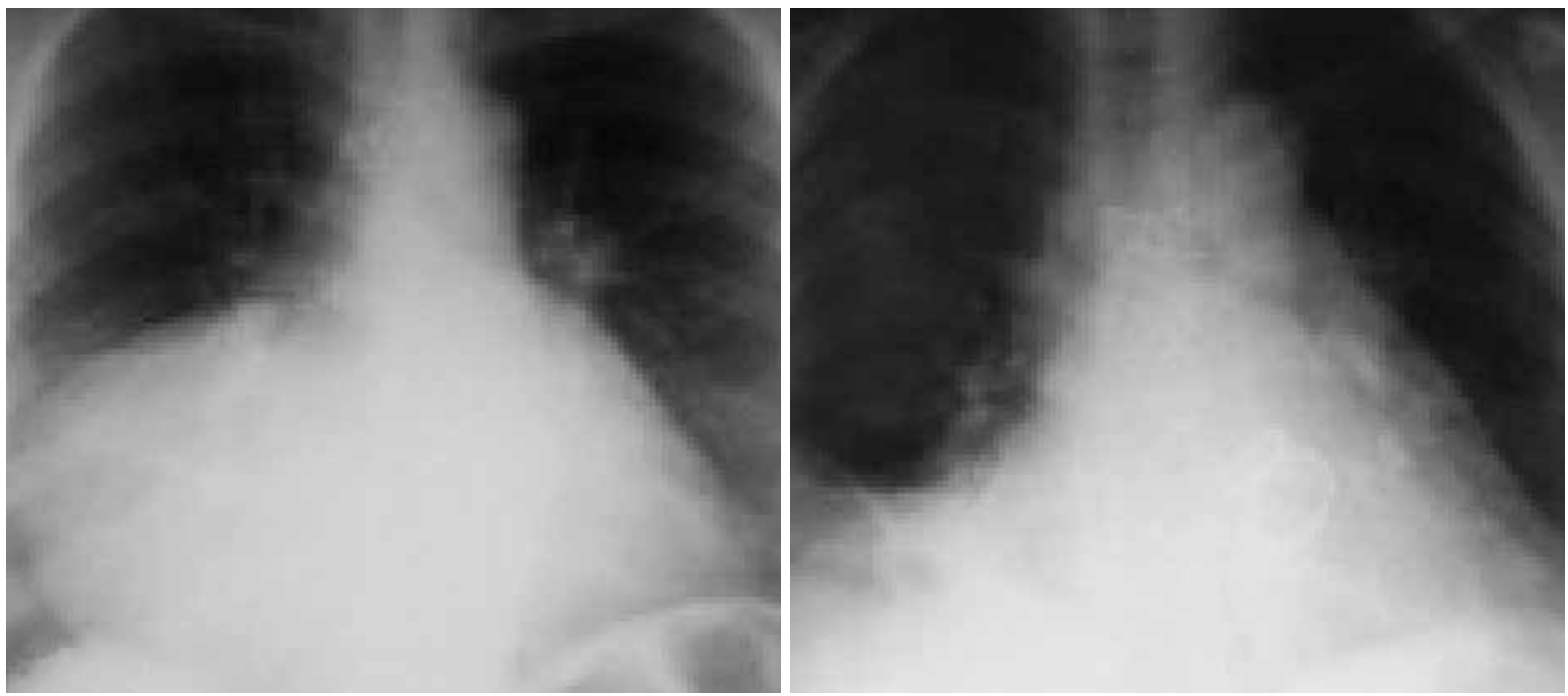

Figure 3. a, b. Preoperative (a) and postoperative (b) demonstration of biatrial size in direct roentenogram.

into AF permanently. What was the reason for them to regain the AF? Should atrial reduction or the Maze procedure be blamed? The reason of this may be due to the ineffectively performed Maze procedure. It may also be related to the reccurrent progressive re-enlargement after the surgery ${ }^{11}$. The atria may reach the initial size by re-enlargement even after an volume reduction surgery ${ }^{1}$. In our study the postoperative measurements of the both atria were observed unchanged even in patients with reccurrent AF occurred after one year following the surgery. This may be due to the increased pressures inside the atria ${ }^{11}$. However, the exact mechanism can't be strictly identified due to the lack of enough information.

Biatrial reduction is an ideal method of treatment to restore the normal atrial geometry. Isolation of the left atrium appendix alone cuts leading AF foci and restricts re-entry fields ${ }^{12}$. On the other hand, remaining unoperated large left atrium may further cause respiratory failure and low postoperative cardiac output that are frequently seen after mitral valve surgery ${ }^{4}$. In our study, RFA was also applied to all cases together with an aggressive volume reduction and suggested to be useful in establishing the sinus rhythm along with respiratory function improvements (Fig. 3).

\section{Conclusion}

Consideration of the surgical treatment in mitral and tricuspid valvular diseases should accompany with the antiarrythmic surgical options, if the patient is suffering AF. The atrial volume reduction method and the Maze procedure are the two options regarding the antiarrythmic surgical treatment. In this study, both options were used together in AF patients. The usage of these two surgical procedures together in cases with AF undergoing a valvular correction surgery may improve postoperative AF incidence in these patients. However, investigations with a limited number of cases need to be supported by larger study populations in the future.

\section{Conflict of Interest}

No conflict of interest was declared.

\section{Funding}

No funding was used during the study.

\section{References}

1. Fredersdorf S, Ücer E, Jungbauer C, Dornia C, Eglmeier J, Eissnert $\mathrm{C}$, et al. Lone atrial fibrillation as a positive predictor of left atrial volume reduction following ablation of atrial fibrillation. Europace 2014;16:26-32.

2. Lundstrom T, Ryden L. Chronic atrial fibrillation: Long term results of direct current conversion. Acta Medica Scandinavica 1988;223:53-9.

3. Üstünsoy H, Şenkaya I, Burma O, Serdar A, Özkan H. Dev Sol Atriyumda Küçültme Ameliyatları. Türkiye Klinikleri J Cardiology 1996;2:96-100. 
4. Johnson J, Danielson GK, MacVaugh H, Joyner CR. Plication of the giant left atrium at operation for severe mitral regurgitation. Surgery 1967;61:118-21.

5. Kawazoe K, Beppu S, Takahara Y, Nakajima N, Tanaka K, Ichihashi K, et al. Surgical Treatment of giant left atrium combined with mitral valvular disease. J Thorac Cardiovasc Surg 1983;85:885-92.

6. Le Roux BT, Gotsman MS. Giant Left Atrium. Thorax 1970;25:190-8.

7. Thomas L, Thomas SP, Hoy M, Boyd A, Schiller NB, Ross DL. Comparison of left atrial volume and function after linear ablation and after cardioversion for chronic atrial fibrillation. Am J Cardiol 2004;93:165-70.

8. Serra AJS, Mc Nicholas N, Lemole KW. Giant left atrium as cause of left pulmonary artery obstruction. Ann Thorac Surg 1987;43:329-31.
9. De Sanctis RW, Dean DC, Bland EF. Extreme left atrial enlargement some characteristic features. Circulation 1964;129:14-23.

10. Moreno JD, Zhu ZI, Yang PC, Bankston JR, Jeng MT, Kang $\mathrm{C}$, et al. A computational model to predict the effects of class I anti-arrhythmic drugs on ventricular rhythms. Sci Transl Med 2011;3(98):98ra83.

11. Kizer JR, Bella JN, Palmieri V, Liu JE, Best LG, Lee ET, et al. Left atrial diameter as an independent predictor of first clinical cardiovascular events in middle-aged and elderly adults: the Strong Heart Study (SHS). Am Heart J 2006;151(2):412-8.

12. Williams MR, Stewart JR, Bolling SF, Freeman S, Anderson JT, Argenziano M, et al. Surgical treatment of atrial fibrillation using radiofrequency energy. Ann Thorac Surg 2001;71:1939-43. 